\title{
PENGEMBANGAN APLIKASI MOBILE E-VOTING PILKADES
}

\author{
Purwono Prasetyawan ${ }^{1}$, Rusliyawati ${ }^{2}$, Devita Sari $^{3}$ \\ ${ }^{1,2,3}$ Fakultas Teknik dan Ilmu Komputer, Universitas Teknokrat Indonesia \\ Jl. ZA Pagaralam No:9-11, Labuhan ratu, Kedaton, Bandarlampung, Lampung \\ 1.purwono.prasetyawan@.teknokrat.ac.id, ${ }^{2}$ rusliyawati@.teknokrat.ac.id, ${ }^{3}$ devitafusia@gmail.com
}

\begin{abstract}
ABSTRAK
Pemilihan kepala desa (Pilkades) pada umumnya masih konvensional dimana menggunakan kertas dalam pemungutan suara. Hal ini dirasa ada kelemahan yaitu berupa, kecepatan waktu perhitungan kertas suara, biaya percetakan kertas suara dan rentan dalam penggelembungan perhitungan suara. Pada penelitian ini bertujuan mengembangkan aplikasi mobile e-voting Pilkades yang diharapkan dapat menyelesaikan masalah pemilihan secara konvensional. Metode pengembangan aplikasi menggunakan waterfall, dimana aplikasi terdiri atas 2 bagian, yaitu front-end berbasis Android untuk pemilih (pengguna) dan back-end berbasis website untuk administrator (pengelola/panitia). Hasil yang diperoleh setelah melakukan pengujian terhadap aplikasi yang telah dikembangkan tersebut adalah secara fungsionalitas semua fitur berjalan lancar dengan metode uji black-box testing dan kompatibel di berbagai versi Android minimal versi Jelly bean ke atas.
\end{abstract}

Kata kunci: Aplikasi mobile, e-Voting, Pilkades, Waterfall, Black-box Testing.

\section{PENDAHULUAN}

Dewasa ini pemilihan kepala desa dilakukan serentak, seperti yang diberitakan pada surat kabar oleh Sitenggang \& Muklasin (2017), bahwa sebanyak 112 desa di Lampung Timur, Provinsi Lampung, pada hari Senin 4 Desember 2017 menggelar Pilkades secara serentak dan di berita harian lainnya oleh Murdaningsih \& Aries (2017), menyampaikan bahwa di Kabupaten Lampung Barat sebanyak 60 Desa menggelar pemilihan kepala desa serentak tanggal 30 Oktober 2017. Ini bisa dibayangkan kerepotannya dalam menghitung kotak suara bila pelaksanaan pemilihan dilakukan secara konvensional. Hal ini menjadi sangat riskan juga, seperti yang sudah dipaparkan oleh Anisiawati (2014), bahwa dalam pelaksanaan pemilihan (voting) sarat akan kecurangan, biasanya terjadi dalam proses perhitungan suara (penggelembungan hasil suara).

Teknologi aplikasi mobile semakin berkembang dan murah di era informasi ini. Internet menjadi kebutuhan pokok, bilamana tidak ada internet, bisa 'mati gaya'. Banyak masyarakat sudah 'melek' internet dan teknologi, bahkan balita pun sudah bisa pegang youtube. Menurut Woodman dalam Sartika (2017) mengenalkan istilah generasi Xenial (diantara genrasi X dengan Mileneal) adalah orang-orang yang lahir pada tahun 1977-1983 dianggap sebagai jembatan dari analog ke digital, generasi yang perlu menyesuaikan diri dengan perkembangan teknologi. Hal ini bisa menjadi pendekatan baru dalam memilih dengan teknologi, selain meminimalisir kecurangan dalam perhitungan suara juga lebih efektif dan efisien dalam hal waktu dan biaya atau tenaga seperti yang disampaikan oleh kepala BPPT, Iskandar (2014).

Menurut Santoso dalam Holifah (2016), pemilihan kepala desa atau seringkali disebut Pilkades, adalah suatu pemilihan kepala desa untuk mencari pemimpin terbaik yang nantinya mempunyai kekuasaan dan wewenang untuk mengendalikan pembangunan desa selama beliau terpilih sebagai kepala desa, yang mengedepankan asas Langsung, Umum, Bebas dan Rahasia (LUBER) oleh warga setempat. Dalam pelaksanaan konvensional sudah menganut asas LUBER, nah bagaimana menjawab tantangan penggunaan aplikasi mobile yang bisa menganut asas ini?

\section{LANDASAN TEORI}

\section{A. Aplikasi Mobile, E-voting dan Pilkades}

Menurut Turban (2012), Aplikasi mobile yaitu istilah yang digunakan untuk mendeskripsikan aplikasi internet yang berjalan di smartphone atau piranti mobile lainnya.Aplikasi mobile biasanya membantu para penggunanya untuk terkoneksi dengan layanan internet yang biasa diakses pada Personal Computer (PC) atau mempermudah mereka untuk menggunakan aplikasi internet pada piranti yang bisa dibawa. Sedangkan menurut Buyens (2001), aplikasi mobile berasal dari kata application dan mobile. Application yang artinya penerapan, lamaran, penggunaan. Secara istilah aplikasi adalah program siap pakai yang direka untuk melaksanakan suatu fungsi bagi pengguna atau aplikasi yang lain dan dapat digunakan oleh sasaran yang dituju. Sedangkan mobile dapat di artikan sebagai perpindahan dari suatu tempat ke tempat yang lain. Berdasarkan dari dua definisi diatas dapat disimpulkan bahwa aplikasi mobile merupakan aplikasi yang terinstall pada perangkat yang bergerak dan tehubung ke intenet, sehingga dapat digunakan dimana saja. 
Menurut Kahani (2005), E-Voting mengacu pada penggunaan komputer atau komputerisasi peralatan pemungutan suara untuk memberikan suara dalam sebuah pemilihan. Sedangkan menurut Rokhman (2011) E-Voting (Electronic voting) adalah proses pemilihan umum yang memungkinkan pemilih untuk mencatatkan pilihannya yang bersifat rahasia secara elektronik yang teramankan. Jadi dari dua definisi tersebut dapat ditarik arti bahwa e-voting suatu mekanisme pemungutan suara secara elektronik dan bersifat rahasia, yang merupakan salah satu asas pemilihan.

Menurut Canard dan Sibert (2001), tujuan dari sistem keamanan e-voting adalah untuk menjamin privasi atau kerahasiaan pemilih serta keakuratan pilihan. Keamanan sistem ini memiliki beberapa kriteria, yaitu :

1) Eligibility,Hanya pemilih yang terdaftar yang dapat melakukan pemilihan.

2) Unreusability, Setiap pemilih hanya dapat memilih satu kali.

3) Anonymity, Pilihan pemilih dirahasiakan.

4) Accuracy, Pilihan tidak bisa diubah dan dihapus selama atau setelah pemilihan

5) Fairness, Perhitungan suara sebelum pemilihan ditutup tidak bisa dilakukan.

6) Vote and Go, Pemilih hanya dapat melakukan pemilihan saja.

7) Public Verifiability, Semua orang dapat melakukan pengecekan pada berjalannya proses pemilihan.

Menurut Badan Pengkajian dan Penerapan Teknologi (BPPT, 2012), Pelaksanaan pemilihan umum pada hakekatnya dapat dibagi menjadi dua cara yakni cara konvensional yang berbasis kertas dan $e$-voting yang berbasis pada teknologi online. E-voting berbasis online dapat dilaksanakan dalam beberapa metode, yaitu :

1) Sistem Pemindaian Optik.

Sistem ini dilakukan dengan cara kertas diberikan kepada para pemilih kemudian hasilnya direkam dan dihitung secara elektronik. Metode ini harus menyediakan surat suara yang dapat dipindai dengan optik dan membutuhkan rancangan yang rumit dan biaya mahal.

2) Sistem Direct Recording Electronic (DRE).

Metode ini para pemilih memberikan hak suaranya melalui komputer atau layar sentuh atau panel/papan suara elektronik. Kemudian hasil pemungutan suara disimpan di dalam memori di TPS dan dapat dikirimkan baik melalui jaringan maupun offline ke pusat penghitungan suara nasional.

3) Internet voting.

Pemilih dapat memberikan hak suaranya dari mana saja secara online melalui komputer yang terhubung dengan jaringan di mana pemungutan suara di TPS langsung direkam secara terpusat. Metode ini membutuhkan jaringan komunikasi data yang berpita lebar dan keamanan yang handal.

Menurut Riera dan Brown (2003), penerapan e-voting diharapkan dapat mengatasi permasalahan yang timbul dari pemilu yang diadakan secara konvensional. Riera dan Brown menawarkan manfaat yang akan diperoleh dalam penerapan $e$-voting, sebagai berikut :

1) Mempercepat penghitungan suara.

2) Hasil penghitungan suara lebih akurat.

3) Menghemat bahan cetakan untuk kertas suara.

Menurut undang-undang RI No.32 (2004) pasal 203 tentang pemerintahan daerah, Pemilihan kepala desa dalam kesatuan masyarakat hukum adat beserta hak tradisionalnya sepanjang masih hidup dan yang diakui keberadaannya berlaku ketentuan, hukum adat setempat yang ditetapkan dalam Perda dengan berpedoman pada peraturan pemerintahan. Penyelenggaraan pemerintah desa tidak dapat lepas dari jabatan kepala desa.Pemerintah desa dipimpin oleh seorang kepala desa yang dipilih masyarakat desa yang sudah mempunyai hak pilih.

\section{B. Waterfall Sebagai Metode Pengembangan Aplikasi}

Menurut Rosa \& Shalahuddin. M (2011), Waterfall merupakan metodologi pengembangan sistem yang menyediakan pendekatan alur hidup perangkat lunak secara sekuensial atau terurut di mulai dari analisis, desain, pengodean, pengujian dan tahap pendukung. Siklus pengembangan sistem menggunakan model waterfall adalah seperti terlihat pada Gambar 1.

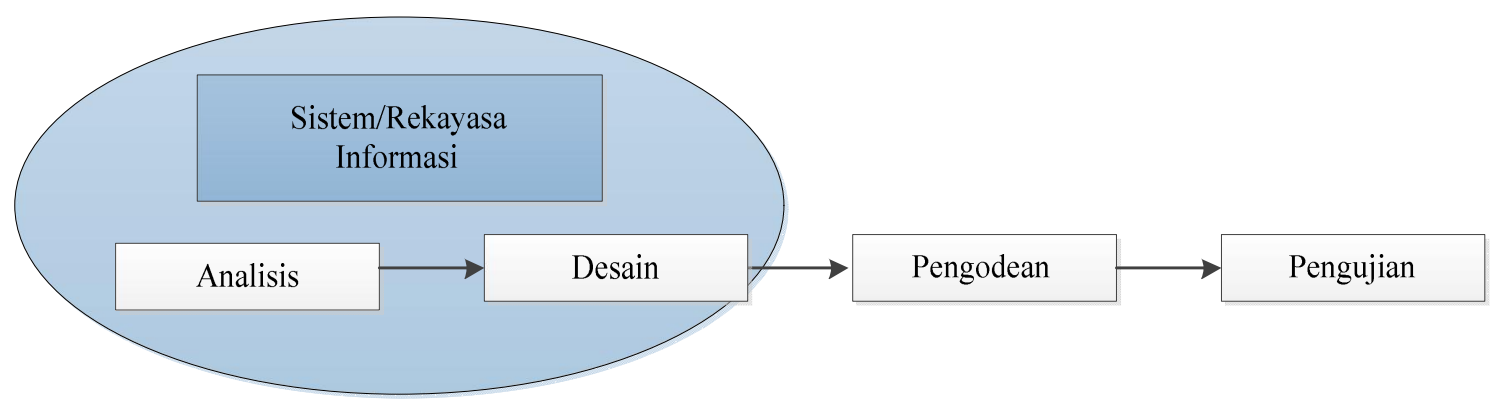




\section{Gambar 1. Metode Waterfall \\ Sumber: Rosa \& Shalahuddin. M (2011)}

Berikut adalah tahapan dalam metode waterfall :

1) Analisis Kebutuhan, proses pengumpulan kebutuhan dilakukan secara intensif untuk menspesifikasikan kebutuhan perangkat lunak agar dapat dipahami perangkat lunak seperti apa yang dibutuhkan oleh user. Spesifikasi kebutuhan perangkat lunak pada tahap ini perlu didokumentasikan.

2) Desain, desain perangkat lunak adalah proses multilangkah yang fokus pada desain pembuatan program perangkat lunak dari tahap analisis kebutuhan kerepresentasi desain agar dapat diimplementasikan menjadi program pada tahap selanjutnya. Desain perangkat lunak pada tahap ini juga perlu didokumentasikan.

3) Pengodean, desain harus ditranlasikan kedalam program perangkat lunak.Hasil dari tahap ini adalah program komputer sesuai desain yang telah dibuat pada tahap desain.

4) Pengujian, pengujian fokus pada perangkat lunak dari segi logic dan fungsional dan memastikan bahwa semua bagian sudah diuji.Hal ini dilakukan untuk meminimalisir kesalahan dan memastikan keluaran yang dihasilkan sesuai dengan yang diinginkan.

\section{METODE PENELITIAN}

Penelitian ini merupakan pengembangan aplikasi dengan menggunakan metode waterfall, dimana ada beberapa tahapan, diantaranya adalah, analisis, desain, pengkodean dan pengujian.

\section{A. Analisis kebutuhan}

\section{Kebutuhan Fungsional}

Kebutuhan fungsional adalah kebutuhan yang berisi proses-proses dan informasi apa saja yang nantinya dilakukan dan dihasilkan oleh sistem. Kebutuhan fungsional dalam Aplikasi E-Voting Pemilihan Kepala Desa, dapat dilihat pada Tabel 1 .

Tabel 1. Kebutuhan Fungsional

\begin{tabular}{|c|c|c|c|}
\hline No. & Form & Fungsi & Keterangan \\
\hline 1. & Login Admin & Form untuk masuk kedalam aplikasi. & $\begin{array}{l}\text { Berupa user name dan password, dan yang bisa } \\
\text { mengakses sistem bagian Admin (Pengurus). }\end{array}$ \\
\hline 2. & Beranda & $\begin{array}{l}\text { Form ini menampilkan Halaman } \\
\text { utama ketika sudah login. }\end{array}$ & Bagian utama beranda pada sistem. \\
\hline 3. & Data Informasi & $\begin{array}{l}\text { Form ini digunakan untuk } \\
\text { menginputkan informasi yang akan } \\
\text { ditampilkan di Beranda. }\end{array}$ & $\begin{array}{l}\text { Bagian ini untuk menginputkan judul dan } \\
\text { keterangan. }\end{array}$ \\
\hline 4. & Data Calon & $\begin{array}{l}\text { Form ini digunakan untuk mengelola } \\
\text { calon kepala desa }\end{array}$ & $\begin{array}{l}\text { Form ini dapat menambah NIK, Nama, Tanggal } \\
\text { Lahir, Alamat, No Urut, Visi, Misi, Foto. }\end{array}$ \\
\hline 5. & Data Pemilih & $\begin{array}{l}\text { Form ini digunakan untuk menginput } \\
\text { data pemilih dan menampilkan status } \\
\text { dari pemilih, sudah memilih atau } \\
\text { belum memilih. }\end{array}$ & $\begin{array}{l}\text { Form ini dapat menginput data pemilih NIK, } \\
\text { Nama, Tanggal Lahir, Jenis Kelamin, Alamat. } \\
\text { Dengan memperhatikan unsur eligibility }\end{array}$ \\
\hline 6. & Pemilihan & $\begin{array}{l}\text { Form untuk menginputkan Mulai } \\
\text { Pemilihan dan Rekapitulasi. }\end{array}$ & $\begin{array}{l}\text { Form ini dapat menginputkan Judul, waktu } \\
\text { Mulai, Selesai, dan Pilih Kandidat. }\end{array}$ \\
\hline 7. & Data Admin & $\begin{array}{l}\text { Form ini untuk menginputkan Data } \\
\text { Admin. }\end{array}$ & $\begin{array}{l}\text { Form ini untuk menginputkan Nama, Email, } \\
\text { Username, Password. }\end{array}$ \\
\hline 8. & Login Pemilih & Form untuk masuk kedalam aplikasi. & $\begin{array}{l}\text { Berupa user name dan password, dan yang bisa } \\
\text { mengakses aplikasi. }\end{array}$ \\
\hline 9. & Profil & $\begin{array}{l}\text { Form ini digunakan untuk melihat } \\
\text { profil diri sebagai data pemilih tetap. }\end{array}$ & $\begin{array}{l}\text { Berupa data diri pemilih, yaitu Nama, Tempat } \\
\text { tanggal lahir, Jenis Kelamin, Alamat. }\end{array}$ \\
\hline 10. & Pilih Calon & $\begin{array}{l}\text { Form ini digunakan untuk langsung } \\
\text { memilih calon yang sudah ditetapkan. }\end{array}$ & $\begin{array}{l}\text { Memasukan data diri berupa NIK dan Tanggal } \\
\text { lahir, dan validasi pemilihan, YA dan TIDAK. } \\
\text { Dengan memperhatikan unreusability, vote \& go }\end{array}$ \\
\hline 11. & Hasil Sementara & $\begin{array}{l}\text { Form ini digunakan untuk melihat } \\
\text { hasil perolehan suara. }\end{array}$ & $\begin{array}{l}\text { Berupa Bagan untuk melihat persentase } \\
\text { pemilihan. Dengan memperhatikan unsur } \\
\text { anonimity, fairness dan public veryfiability }\end{array}$ \\
\hline 12. & Rekapitulasi & $\begin{array}{l}\text { Form ini digunakan untuk melihat } \\
\text { hasil rekapan akhir. }\end{array}$ & $\begin{array}{l}\text { Berupa Total memilih, Total belum memilh, dan } \\
\text { Total suara. Dengan memperhatikan unsur } \\
\text { anonimity dan accuracy }\end{array}$ \\
\hline 13. & Petunjuk & $\begin{array}{l}\text { Form ini digunakan untuk melihat } \\
\text { dan mempelajari cara pemilihan. }\end{array}$ & Berupa petunjuk pemilihan. \\
\hline
\end{tabular}

\section{Kebutuhan non Fungsional}


Kebutuhan non fungsional ini melihat apa saja yang dibutuhkan saat pengembangan aplikasi dan saat implementasi aplikasi bila sudah jadi. Kebutuhan ini merupakan spesifikasi minimal yang harus ada, supaya bisa mengembangkan dan menjalankan aplikasi. Kebutuhan non fungsional terdiri dari hardware dan software saat pengembangan dan implementasi, diantaranya dapat dilihat pada Tabel 2 berikut.

Tabel 2. Kebutuhan non Fungsional

\begin{tabular}{clll}
\hline No. & $\begin{array}{l}\text { Kebutuhan } \\
\text { non Fungsional }\end{array}$ & Pengembangan & Implementasi \\
\hline 1. & Hardware & $\begin{array}{l}\text { Laptop core i3, RAM 2Gb. } \\
\text { Smartphone Android }\end{array}$ & $\begin{array}{l}\text { Hosting/server } \\
\text { Smartphone }\end{array}$ \\
2. & Software & $\begin{array}{l}\text { Xampp } \\
\text { Internet Browser } \\
\text { Converter Web to Apk }\end{array}$ & OS Android versi Jelly bean up \\
\hline
\end{tabular}

\section{B. Desain}

Desain aplikasi secara fungsi bisa digambarkan dengan usecase diagram seperti pada Gambar 2 berikut.

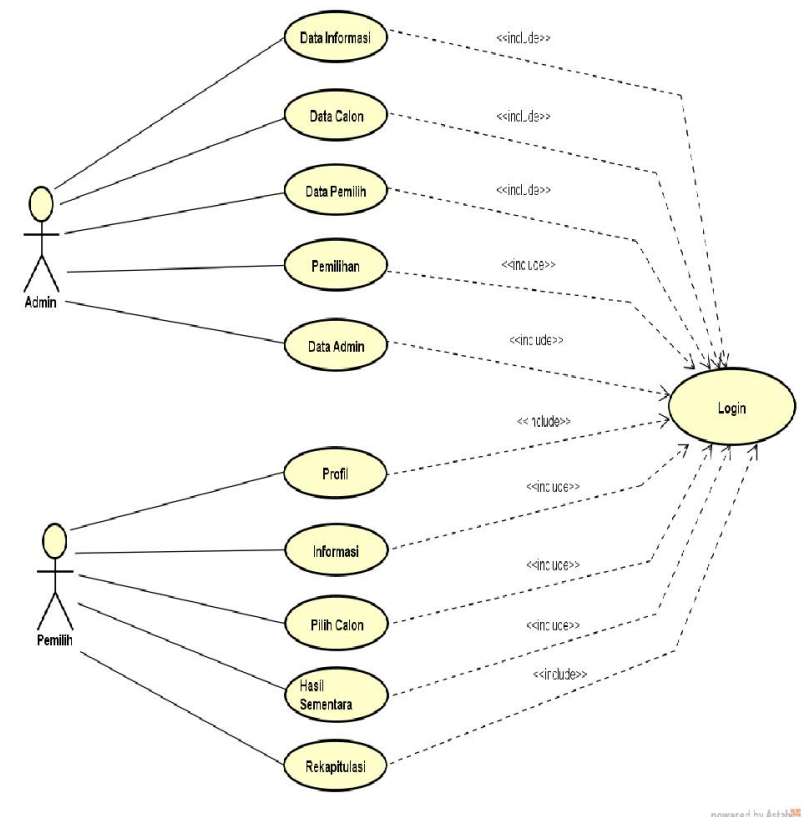

Gambar 2. Usecase Diagram
Dalam Sistem pemilihan ini ada 2 aktor, yaitu administrator (panitia) dan user (pemilih). Dimana fungsi atau fitur yang ditawarkan untuk panitia bisa mengelola data informasi, calon, pemilih, pemilihan dan data admin. Sedangkan untuk pemilih setelah login bisa membaca informasi, memilih calon, melihat hasil sementara dan hasil rekapitulasi akhir, seperti terlihat pada Gambar 3. Kemudian supaya bisa menjaga kerahasian dibutuhkan password untuk login.
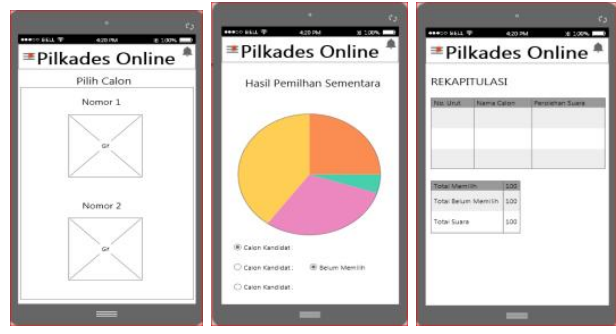

Gambar 3. Rancangan Interface

\section{Pengodean \& Pengujian}

Pada sisi panitia (administrator) dikembangkan dengan bahasa pemrograman web yaitu PHP dan database MySql. Sedangkan di sisi pemilih (user) dikembangkan berbasis mobile: android, dengan minimal versi jelly bean. Beikut hasil aplikasi yang sudah dikembangkan, bisa dilihat pada Gambar 4 . 


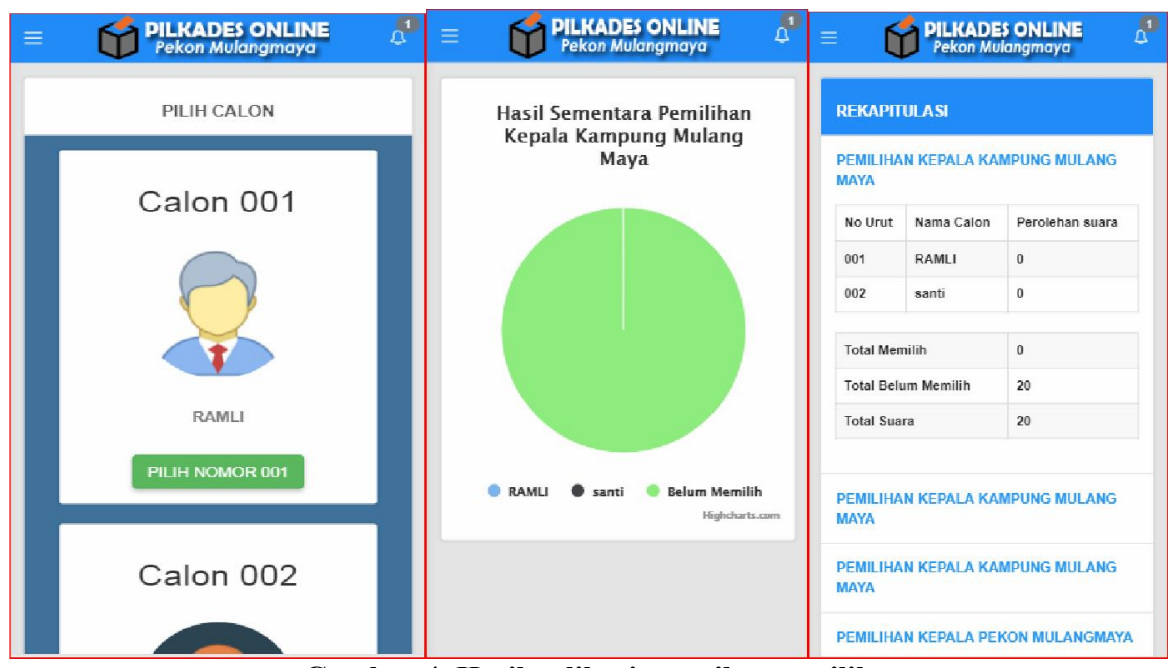

Gambar 4. Hasil aplikasi tampilan pemilih

Aplikasi ini diuji baik secara fungsionalitas maupun kompatibilitas. Secara fungsionalitas menggunakan metode black-box testing, sedangakan untuk kompatibilitas, yaitu dengan mencoba di beberapa smarthpone dengan versi Android diatas versi jelly bean.

\section{HASIL DAN PEMBAHASAN}

Hasil dari penelitian ini adalah berupa aplikasi mobile evoting pemilihan kepala desa, dimana sudah diuji dibeberapa spesifikasi smartphone dengan beberapa versi android, untuk dilihat kompatibel-nya. Hasil uji bisa dilihat pada Tabel 3

Tabel 3. Uji Kompatibilitas

\begin{tabular}{clllc}
\hline NO & \multicolumn{1}{c}{ Merk } & \multicolumn{1}{c}{ Layar } & \multicolumn{1}{c}{ Versi } & Hasil Uji \\
\hline 1. & Xioami Redmi Note 3 Pro & 5.5 inch, 1080x1920 pixels & 5.5 .1 Lolipop & Lancar \\
2. & Sony Xperia S (LT26i) & 4.30 inch, 720x1280 pixels & 4.1 .2 Jelly Bean & Lancar \\
3. & Xioami Mi4i & 5 inch, 1080x1920 pixels & 5.0 .2 Lollipop & Lancar \\
4. & Vivo y21 & 4.5 inch, 480x854 pixels & 5.1 .1 Lollipop & Lancar \\
5. & Xioami Mi5 & 5.15 inches, 1080x1920 pixels & 6.0 Maeshmellow & Lancar \\
\hline
\end{tabular}

Hasil uji aplikasi dengan metode blackbox testing dapat dilihat pada Tabel 4. Hal ini menentukan apakah sesuai atau tidak dengan rancangan/desain awal, terhadap hasil akhir

Tabel 4. Uji Fungsionalitas

\begin{tabular}{clll}
\hline No. & Form & Fungsi & Keterangan Hasil Uji \\
\hline 1. & Login Admin & Form untuk masuk kedalam aplikasi & Sesuai, sesuai sekenario fungsi login \\
2. & Beranda & $\begin{array}{l}\text { Form ini menampilkan Halaman } \\
\text { utama ketika sudah login. }\end{array}$ & Sesuai, setelah login masuk beranda \\
3. & Data Informasi & $\begin{array}{l}\text { Form ini digunakan untuk } \\
\text { menginputkan informasi yang akan } \\
\text { ditampilkan di Beranda. }\end{array}$ & Sesuai, bisa mengelola data informasi pemilihan \\
4. & Data Calon & $\begin{array}{l}\text { Form ini digunakan untuk mengelola } \\
\text { calon kandidat kepala desa yang } \\
\text { terpilih. }\end{array}$ & Sesuai, dapat mengelola calon kandidat \\
5. & Data Pemilih & $\begin{array}{l}\text { Form ini digunakan untuk menginput } \\
\text { data pemilih dan menampilkan status } \\
\text { dari pemilih, sudah memilih atau } \\
\text { belum memilih. }\end{array}$ & Sesuai, bisa mengelola data pemilih \\
6orm untuk mengelola Mulai & Sesuai, bisa membuat event pemilihan \\
6. Pemilihan dan Rekapitulasi. & $\begin{array}{l}\text { Form ini untuk mengelola Data } \\
\text { Admin. }\end{array}$ & Sesuai, bisa mengelola data panitia \\
7. & Dorm untuk masuk kedalam aplikasi. & Sesuai, masuk bila username, password sesuai \\
\hline
\end{tabular}




\begin{tabular}{|c|c|c|c|}
\hline 9. & Profil & $\begin{array}{l}\text { Form ini digunakan untuk melihat } \\
\text { profil diri sebagai data pemilih tetap. }\end{array}$ & Sesuai, dapat melihat profil diri pemilih \\
\hline 10. & Pilih Calon & $\begin{array}{l}\text { Form ini digunakan untuk langsung } \\
\text { memilih calon yang sudah ditetapkan. }\end{array}$ & Sesuai, bisa digunakan untuk voting suara \\
\hline 11. & Hasil Sementara & $\begin{array}{l}\text { Form ini digunakan untuk melihat } \\
\text { hasil perolehan suara. }\end{array}$ & Sesuai, bisa menampilkan hasil sementara \\
\hline 12. & Rekapitulasi & $\begin{array}{l}\text { Form ini digunakan untuk melihat } \\
\text { hasil rekapan akhir. }\end{array}$ & Sesuai, dapat menampilkan hasil rekapitulasi \\
\hline
\end{tabular}

Dalam menjamin penyelengaraan pemilihan e-voting ini berasaskan LUBER, maka 7 (tujuh) kriteria keamanan sistem e-voting menurut Canard \& Sibert (2001) harus terpenuhi. Berikut meupakan pembahasan dari aplikasi yang sudah dikembangkan dalam menguji apakah terpenuhi atau belum?

1) Eligibility, Hanya pemilih yang terdaftar yang dapat melakukan pemilihan.

Terpenuhi, bahwa dimana aplikasi back-end panitia mengelola Data Pemilih Tetap (DPT), artinya yang eligibel yang bisa login sebagai pemilih.

2) Unreusability, Setiap pemilih hanya dapat memilih satu kali.

Terpenuhi, dalam aplikasi pemilih, menu pilih calon akan tidak aktif, bilamana sudah memilih

3) Anonymity, Pilihan pemilih dirahasiakan.

Terpenuhi, bahwa baik di sisi panitia dan pemilih tidak dapat melihat data yang sudah dipilihnya

4) Accuracy, Pilihan tidak bisa diubah dan dihapus selama atau setelah pemilihan

Terpenuhi, aplikasi bisa menghitung cepat dan akurat, tidak bisa diubah dan dihapus datanya baik oleh panitia maupun pemilih.

5) Fairness, Perhitungan suara sebelum pemilihan ditutup tidak bisa dilakukan.

Terpenuhi, aplikasi tidak akan menghitung hasil sementara lagi di H-2 jam dari penutupan.

6) Vote and Go, Pemilih hanya dapat melakukan pemilihan saja.

Tidak terpenuhi, bahwadisisi pemilih, banyak fungsi selain pemilihan, misalnya liat profil diri.

7) Public Verifiability, Semua orang dapat melakukan pengecekan pada berjalannya proses pemilihan.

Terpenuhi, bahwa disisi pemilih dapat melihat hasil perhitungan baik sementara atau rekapitulasi akhir.

\section{SIMPULAN DAN SARAN}

Simpulan dalam penelitian ini adalah sebagai berikut:

1) Aplikasi mobile e-voting pemilihan kepala desa berhasil dikembangkan berbasis android.

2) Aplikasi ini kompatibel terhadap berbagai versi Android, minimal android versi jelly bean ke atas

3) Secara functionality aplikasi yang dikembangkan dapat berjalan sesuai dan lancar di semua fiturnya.

4) Sebagian besar aplikasi memenuhi kriteria e-Voting yang aman, LUBER.

Adapun saran yang disampaikan yang pertama adalah mengenai keamanan pada aplikasi ini secara teknis belum diuji, bagaimana supaya kerahasiaan data tetap terjaga, sebagai salah satu asas pemilihan, Rahasia. Kemudian bisa dihilangkan fitur melihat profil diri pemilih, yang tidak memenuhi kriteria Vote \& Go.

\section{DAFTAR PUSTAKA}

Anistiawati, M.L. (2014). Implementasi Kebijakan Penerapan Elektronik Voting (E-Voting) Dalam Pemilihan Kepala Desa (Studi Kasus : Pemilihan Kepala Desa Mendoyo Dangin Tukad, Kecamatan Mendoyo Kabupaten Jembrana). Citizen Charter Journal, Vol 1 No 2. FISIP Universitas Udayana

BPPT. (2012). Berita Teknologi Informasi, Energi \& Material, E-Voting Demokrasi di Ujung Jari. Diakses pada 4 april 2018. http://www.bppt.go.id/teknologi-informasi-energi-dan-material/1869-e-votingdemokrasi-di-ujung-jari-

Buyens, J. (2001). Web Database Development, Step by Step. Jakarta : Elex Media Komputindo

Canard, S., \& Sibert, H. (2001). How To Fit Cryptograhic E-Voting Into Smart Cards. Perancis: IOS Press.

Holifah, N. (2016). Politik dinasti : studi kasus kemenangan dinasti samidin dalam pilkades di desa banjar kec. Kedungdung kab. Sampang. Undergraduate thesis, UIN Sunan Ampel Surabaya. website: http://digilib.uinsby.ac.id/6385/

Iskandar, M.A. (2014). E-Voting Untuk Pemilu 2014. diakses pada 4 april 2018. https://www.bppt.go.id/teknologi-informasi-energi-dan-material/425-e-voting-untuk-pemilu-2014 
Kahani, M. (2005). Experiencing small-scale e-democracy in Iran. The Electronic Journal On Information System in Developing Countries, 1-9.

Murdaningsih, D. \& Aries,M. (2017). Lampung Barat Gelar 60 Pilkades Serentak. diakses pada 4 April 2018. http://nasional.republika.co.id/berita/nasional/daerah/17/10/31/oynrbr368-lampung-barat-gelar60-pilkades-serentak

Riera, A., \& Brown, P. (2003). Bringing Confidence to Electronic Voting. Electronic Journal of eGovernment, 14-21.

Rokhman, A. (2011). Prospek dan Tantangan. Penerapan e-Voting di Indonesia. Seminar Nasional. Peran Negara dan Masyarakat dalam Pembangunan. Demokrasi dan Masyarakat Madani di Indonesia, 7. Juli 2011. Jakarta: Universitas Terbuka

Rosa, A.S. \& Shalahudin,M. (2011). Rekayasa Perangkat Lunak Terstruktur dan Beorientasi Objek. Bandung: Modula.

Sartika, R.E.A. (2017). Mengenal Xenial, Generasi Baru antara Generasi X dan Milenial. diakses pada 4 April 2018. https://sains.kompas.com/read/2017/11/06/200600123/mengenal-xenial-generasi-baruantara-generasi-X-dan-milenial

Sitanggang, H. \& Muklasin. (2017). 112 Desa di Lampung Timur Gelar Pilkades. diakses pada 4 april 2018. https://lampung.antaranews.com/berita/301392/112-desa-di-lampung-timur-gelar-pilkades

Turban, E. (2012). Electronic Commerce 2012. Pearson 7th-Global Edition 